\title{
Accounting and Stock Market Performance in the US: Evidence from Joiners and Leavers
}

\author{
Christos Floros $^{{ }^{*}}{ }^{\text {, Efthalia Tabouratzi }}{ }^{1}$, Dimitris Charamis ${ }^{2}$, Stella Zounta ${ }^{3}$ \\ ${ }^{1}$ Department of Accounting and Finance, Technological Educational Institute of Crete, Crete, Greece \\ ${ }^{2}$ Department of Business Administration University of Patras, Patras, Greece \\ ${ }^{3}$ Business School, University of the Aegean, Chios, Greece \\ Email: *cfloros@staff.teicrete.gr, dcharamis@gmail.com, szounta@aegean.gr
}

How to cite this paper: Floros, C., Tabouratzi, E., Charamis, D. and Zounta, S. (2017) Accounting and Stock Market Performance in the US: Evidence from Joiners and Leavers. Theoretical Economics Letters, 7, 696-708.

https://doi.org/10.4236/tel.2017.74050

Received: April 12, 2017

Accepted: May 14, 2017

Published: May 17, 2017

Copyright (C) 2017 by authors and Scientific Research Publishing Inc. This work is licensed under the Creative Commons Attribution International License (CC BY 4.0).

http://creativecommons.org/licenses/by/4.0/

\begin{abstract}
We consider recent data from three major US indices (S \& P500, NASDAQ 100 , and DJIA) to examine the effect of joiners and leavers on stock market returns and volatility. We report (a) a positive effect of leavers on stock market returns (S \& P500, DJIA), (b) a positive effect of leavers on stock market volatility (S \& P500), and (c) a negative effect of joiners on DJIA stock market returns and volatility. No effects reported for NASDAQ100. We compare these results with the profitability, P/E and Price to Book index ratios. These findings are recommended to financial managers and investors dealing with US stock indices.
\end{abstract}

\section{Keywords}

Stock Market Returns, Volatility, Index Ratios, US, Joiners, Leavers, GARCH

\section{Introduction}

The literature views the size of the stock market as a measure of financial development [1]. Stock markets provide several benefits as a source of external capital by reducing asymmetric information. Other benefits include low cost of capital and innovation in firms; see Acharya and Xu [2]. They report that firms in more innovation intensive industries with a greater need for external capital are more likely to go public. Going public is the most fundamental form of increasing liquidity [3]. Moreover, Pour et al. [4] show that, during the first two years of listing, leverage of delisted firms increased, but their profitability and equity market value decreased, while their market to book remained constant. Jensen [5] reports that publicly listed firms suffer from the agency conflict between manager and shareholders. Firms with significant free cash flows as well as low growth 
opportunities are more likely to go private [4]. Firms trade off the costs and benefits of being listed (joined) in the stock market when they decide to delist (leave), see Pour et al. [4]. The reasons behind the listing/delisting decision remain an open research question.

The benefits of listing on a stock exchange include relaxing borrowing constraints, recognition of investors and greater bargaining power with banks [4]. They further mention that "... listing is subject to substantial direct costs such as compliance and ministering costs, underwriting and registration fees, and indirect costs with relate to the adverse selection and agency conflicts". Further, successful firms which remain listed on the market contribute to the economic growth.

A number of studies report why firms decide to list (join) or delist (leave) the stock exchange; further, there is a debate on whether listing and delisting affect stock price of firm. Sanger and Peterson [6] and Macey et al. [7] explain the liquidity hypothesis. In other words, the reduction in liquidity as well as the increase in liquidity risk is the main reasons for the negative effect of delisting on the stock price [8]. Pour et al. [4] report that delisted firms have lower liquidity and financial visibility as measured by stock turnover, trading volume and stock volatility; these firms have low growth opportunities but high leverage and information asymmetries. The delisted firms show a price decline long before the delisting decision is announced. Moreover, Fama and French [9] show that newly listed US firms have higher growth and lower profitability.

Previous studies report that the delisting decision has a significant negative effect on the stock price of US firms. Sanger and Peterson [6] report a fall of about $8.5 \%$ in the stock price of delisting firms on the delisting announcement day. Further, Angel et al. [10] find that the US investors experience a loss of about $22 \%$ in 60 days prior to delisting.

A number of studies have advanced motivations for why firms list in the US. Firms may be motivated to list to gain lower costs of capital associated with more efficient risk sharing [11] or greater investor recognition [12], greater access to capital [13], improved liquidity [14], or improved product market visibility [15]; see also Chaplinsky and Ramchand [16].

In the US, companies must meet all financial, liquidity and corporate governance criteria (requirements) which are given from the stock market in order then to be approved for listing on the market, and include: Pre-tax earnings; cash flows; market capitalization; revenue; total assets; stockholders' equity; bid price; total shareholders; average monthly trading volume; publicly held shares; market value of publicly held shares; market makers; distribution of annual or interim reports; independent directors; audit committee, etc. The NASDAQ stock market reports that it generally takes four to six weeks to process a listing application. Further, firms delist from the US exchanges (NYSE, AMEX, NASDAQ) -it takes about 21 days-and then they deregister from the SEC. The deregistration process takes up to 60 days [4].

Beaver et al. [17] argue that the treatment of delisting returns can have a sig- 
nificant impact on estimated returns associated with trading strategies based on variables of great interest to accounting researchers. They show that tests of market efficiency are sensitive to the inclusion of delisting firm-years. They report that trading strategy returns based on anomaly variables can increase (for strategies based on earnings, cash flows and the book-to-market ratio) or decrease (for a strategy based on accruals); see Beaver et al. [17] for more details. They also find that exclusion of firms that are delisted in the year $t+1$ return accumulation period, i.e. delisting firm-years, does not uniformly increase or decrease portfolio returns.

The economic (and accounting) effect of joiners and leavers on stock markets (returns and volatility) is a matter of debate. In this paper, we examine whether US listed and delisted announcements affect the major stock market indices from NYSE (S \& P500, Dow Jones Industrial Average Index or DJIA) and NASDAQ (NASDAQ100) over the period 1996-2016. In particular, the aim of this paper is to examine the effect of joiners and leavers announcements on both the US stock market returns and volatility. We also report the link between joiners and leavers announcements with the stock market performance. This is highly important as competition between firms is related to their performance which influences investors' decision making. Hence, the contribution of this paper to the existing literature is that it reports not only the empirical results from financial econometrics but also financial index ratios (price statistics). Moreover, our sample includes a long period of US stock market crashes and bear markets: Dot-com bubble of $10^{\text {th }}$ March 2000; September $11^{\text {th }} 2001$ attacks; Stock market downturn of $9^{\text {th }}$ October 2002; US bear market of 2007-2009; US financial crisis of 2007-2008; August 2011 stock market fall; 2015-16 stock market selloff. In total, there are 1717 announcements for S \& P500, 65 for DJIA and 665 for NASDAQ100 over the examined period.

A stylized fact of financial volatility, that bad news (negative shocks) tends to have a larger impact on volatility than good news (positive shocks), is considered. That is, volatility tends to be higher in a falling market than in a rising market [18]. We model the fact that bad news (delisting) tends to drive down the stock price, thus increasing the leverage of the stock and causing the stock to be more volatile after a particular announcement using an asymmetric GARCH model (i.e. we test if listing announcements have a different effect on volatility and stock market returns than delisting announcements). We find that joiners and leavers announcements do matter and affect the stock markets. In particular, we report (a) a positive effect of leavers on stock market returns (S \& P500, DJIA), (b) a positive effect of leavers on stock market volatility (S \& P500), and (c) a negative effect of joiners on DJIA stock market returns and volatility. No effects reported for NASDAQ100; the reason is that NASDAQ100 reported high P/E and Price to Book ratios over the examined period (see Table 1 with index ratios). Our results have significant policy implications.

The remainder of the article is structured as follows. Section 2 describes the method and data used. Section 3 presents the empirical results, and Section 4 concludes the paper. 
Table 1. Price Statistics. (a) NYSE vs. NASDAQ*; (b) S \& P500 Price Statistics: 1996-2016 (source: Thomson Reuters); (c) NASDAQ 100 Price Statistics: 1996-2016 (source: Thomson Reuters); (d) DJIA Price Statistics: 1996-2016 (source: Thomson Reuters).

(a)

\begin{tabular}{ccc}
\hline & NYSE & NASDAQ \\
\hline Aggregate market capitalization & US\$ 12,465 billion & US\$ 3775 billion \\
$\begin{array}{c}\text { Number of listed companies } \\
\text { (excluding investment funds) }\end{array}$ & 2318 & 2712 \\
Domestic companies & 1801 & 2409 \\
Foreign companies & 517 & 303 \\
$\begin{array}{c}\text { Top 3 sectors by number } \\
\text { of listed companies } \\
\text { (excluding investment funds) }\end{array}$ & $\begin{array}{c}\text { Financials, industrials, } \\
\text { consumer discretionary }\end{array}$ & $\begin{array}{c}\text { Information technology, } \\
\text { financials, healthcare }\end{array}$ \\
\hline
\end{tabular}

*Source: August 2011 Complete report of World Federation of Exchanges (Americas region of NASDAQ OMX and NYSE Euronext (US)).

(b)

\begin{tabular}{|c|c|c|c|c|}
\hline \multicolumn{3}{|c|}{ Price } & & \\
\hline High & 2213.35 & 25-Nov.-2016 & & \\
\hline Low & 666.79 & 06-Mar.-2009 & & \\
\hline Avg. & 1326.74 & & & \\
\hline \multicolumn{2}{|c|}{ Up/Down (C-C) } & Price Change & \multicolumn{2}{|c|}{ Close-Close } \\
\hline Up & 2672 & Up & $+11.58 \%$ & 13-Oct.-2008 \\
\hline Down & 2359 & Down & $-9.03 \%$ & 15-Oct.-2008 \\
\hline Unch & 2 & Period & $+192.79 \%$ & Custom \\
\hline \multicolumn{5}{|c|}{ Index Ratios } \\
\hline \multicolumn{2}{|c|}{$\mathrm{P} / \mathrm{E}$} & \multicolumn{3}{|c|}{21.21} \\
\hline \multicolumn{2}{|c|}{ Market Cap } & \multicolumn{3}{|c|}{$21.31 \mathrm{~T}$} \\
\hline \multicolumn{2}{|c|}{ Div Yld \% } & \multicolumn{3}{|c|}{2.40} \\
\hline \multicolumn{2}{|c|}{ Price to Book } & \multicolumn{3}{|c|}{2.87} \\
\hline
\end{tabular}

(c)

\begin{tabular}{|c|c|c|c|c|}
\hline \multicolumn{3}{|c|}{ Price } & & \\
\hline High & 4911.763 & 25-Oct.-2016 & & \\
\hline Low & 779.170 & 03-Apr.-1997 & & \\
\hline Avg. & 2230.133 & & & \\
\hline \multicolumn{2}{|c|}{ Up/Down (C-C) } & Price Change & \multicolumn{2}{|c|}{ Close-Close } \\
\hline Up & 2710 & Up & $+18.77 \%$ & 03-Jan.-2001 \\
\hline Down & 2320 & Down & $-10.52 \%$ & 29-Sept.-2008 \\
\hline Unch & 3 & Period & $+489.94 \%$ & Custom \\
\hline
\end{tabular}




\begin{tabular}{cc}
\hline & Index Ratios \\
\hline P/E & 24.97 \\
Market Cap & $6.54 \mathrm{~T}$ \\
Div Yld \% & - \\
Price to Book & 5.03 \\
\hline
\end{tabular}

(d)

\begin{tabular}{|c|c|c|c|c|}
\hline \multicolumn{3}{|c|}{ Price } & & \\
\hline High & 19152.14 & 25-Nov.-2016 & & \\
\hline Low & 6236.05 & 17-Dec.-1996 & & \\
\hline Avg. & 11646.22 & & & \\
\hline \multicolumn{2}{|c|}{ Up/Down (C-C) } & Price Change & \multicolumn{2}{|c|}{ Close-Close } \\
\hline Up & 2644 & Up & $+11.08 \%$ & 13-Oct.-2008 \\
\hline Down & 2385 & Down & $-7.87 \%$ & 15-Oct.-2008 \\
\hline Unch & 4 & Period & $+193.37 \%$ & Custom \\
\hline \multicolumn{5}{|c|}{ Index Ratios } \\
\hline \multicolumn{2}{|r|}{$\mathrm{P} / \mathrm{E}$} & & \multicolumn{2}{|c|}{19.33} \\
\hline \multicolumn{2}{|r|}{ Market Cap } & & \multicolumn{2}{|c|}{$5.97 \mathrm{~T}$} \\
\hline \multicolumn{2}{|r|}{ DivYld \% } & & \multicolumn{2}{|c|}{2.45} \\
\hline \multicolumn{2}{|r|}{ Price to Book } & & \multicolumn{2}{|c|}{3.39} \\
\hline
\end{tabular}

\section{Methodology and Data}

This paper uses TGARCH (Threshold Generalized Autoregressive Conditional Heteroskedasticity) time series analysis to empirically examine the behaviour of investors after a listing/delisting announcement, i.e. we investigate the link between US firms' performance and the stock market returns/volatility. According to Reider [19], "When stocks drop, the debt/equity ratios increase and stocks become more volatile with higher leverage ratios. But the changes in volatility associated with stock market drops are much larger than that which could be explained by leverage alone. One model to account for this asymmetry is the Threshold GARCH (TGARCH) model."

In our study, we use (a) a threshold GARCH (TGARCH) method which captures good and bad news (announcements), and (b) recent data from three major US indices (S \& P500, NASDAQ100, DJIA)-for comparison reasons. The data includes announcements of joiners and leavers and is collected from Thomson Reuters. Following the availability of financial data, we cover a long period for announcements, i.e. 1996-2016. S \& P500 index reported 606 and 1111 announcements for leavers and joiners, respectively. In addition, DJIA index reported 21 and 44 announcements for leavers and joiners, respectively; NASDAQ100 index reported 281 and 384 announcements for leavers and joiners, respectively.

Previous studies report that the delisting decision has a significant negative 
effect on the stock price; hence, we investigate these effects using dummies. We use a TGARCH model which captures an effect where negative shocks have a greater volatility impact than positive shocks; we test if this effect is significant on both the stock returns and volatility. Both AIC and SIC information criteria select the parsimonious $\operatorname{AR}(1)$-TGARCH $(1,1)$ model which accounts for temporal dependence in variance and excess kurtosis, while it controls the effect of good/bad news on conditional variance [20] [21]; further, we model returns using an $\mathrm{AR}(1)$ mean equation, consistently with the non-synchronous trading effect [22]. The AR(1)-TGARCH $(1,1)$ model for returns ${ }^{1} R$ is given by:

$$
\begin{gathered}
R_{t}=c_{1} R_{t-1}+c_{2} D_{\mathrm{LEAVEt}}+c_{3} D_{\mathrm{JOIN} t}+\varepsilon_{t} \\
\sigma_{t}^{2}=\omega+\alpha_{1} \varepsilon_{t-1}^{2}+\gamma \varepsilon_{t-1}^{2} d_{t-1}+\beta_{1} \sigma_{t-1}^{2}
\end{gathered}
$$

The specification for the conditional mean is given by Equation (1) where dummies $D_{\text {LEAVEt }}, D_{\text {JoIN }}$ test for the delisting (leave) and listing (join) effects, respectively. Dummies take the value 1 for the date of announcement, and 0 otherwise.

The specification for the conditional variance is given by Equation (2) where $d_{t}=1$ if $\varepsilon_{t}<0$ and $d_{t}=0$ otherwise. In TGARCH model, good news $\left(\varepsilon_{t}>0\right)$ and bad news $\left(\varepsilon_{t}<0\right)$ have differential effects on the conditional variance. In particular, good news has an impact of $a$, while bad news has an impact of $a+\gamma$. If $\gamma>0$ and significant, then the leverage effect exists and bad news increases volatility. If $\gamma \neq 0$ the news impact is asymmetric ${ }^{2}$, while if $\gamma=0$ then the news impact curve is symmetric [20] [21].

\section{Empirical Results}

Table 1 presents the price statistics and index ratios for all three US indices over the examined period, 1996-2016. In addition, Figure 1 shows the NYSE Group accounting performance: plots of Turnover (decrease after 2008) as well as market credit (margin debt and credit balances in margin accounts) before and after the US financial crisis of 2007-2008. Moreover, descriptive statistics results of daily stock index prices of S \& P500, DJIA and NASDAQ100 over the examined period (not reported here) confirm that all of the returns series follow the stylised facts of financial time series such as leptokurtosis, volatility clustering and leverage effects [23]; in addition, the log levels of prices are found to be I (1), i.e. the series are non-stationary ${ }^{3}$. Hence, we are able to use GARCH-family models to capture volatility clustering (as showing in Figure 2 ) and test the link between listing (joiners) and delisting (leavers) announcements and stock market indices (returns and volatility).

The empirical (econometrics) results on the effect of joiners and leavers on the returns and volatility of the stock indices using EViews software are presented in Table 2 and Table 3, respectively. In Table 2, we report the results

${ }^{1}$ Daily returns are computed as logarithmic price relatives: $R_{t}=\ln \left(P_{t} / P_{t-1}\right)$, where $P_{t}$ is the daily price at time $t$.

${ }^{2}$ The $\gamma$ parameter catches asymmetry in the response of volatility to shocks [24].

${ }^{3}$ These results are not reported to save space but they are available upon request. 


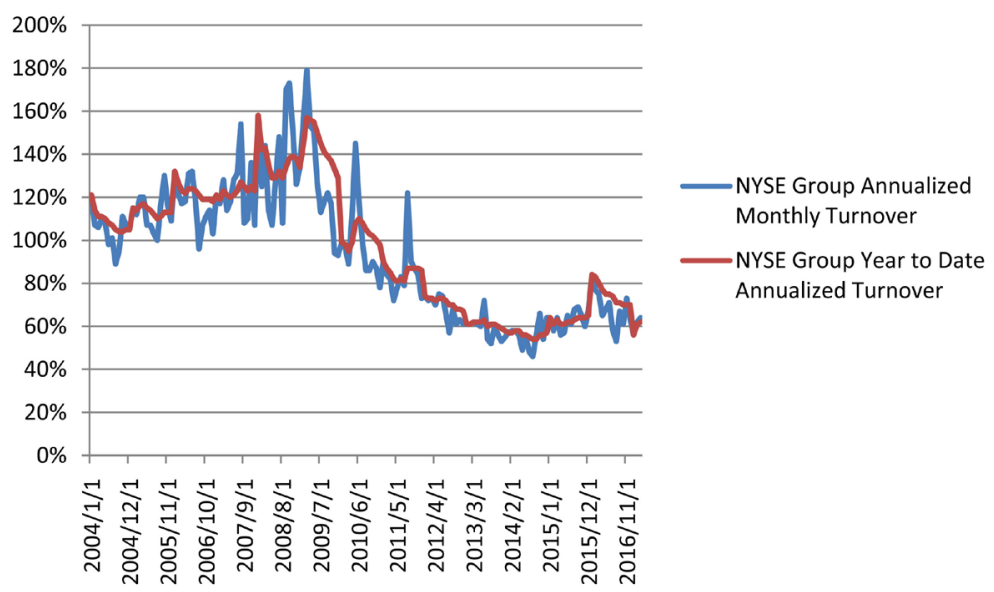

(a)

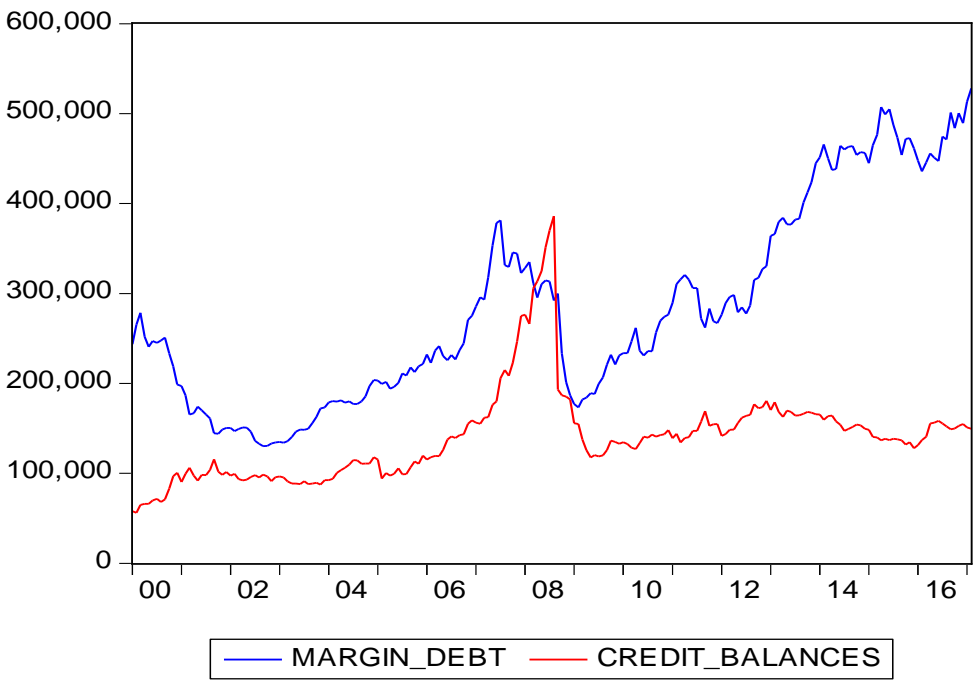

(a)

Figure 1. Plots of NYSE Group Turnover and Market Credit (Monthly; 2004-2017). (a) Turnover; (b) Market credit; $\$$ in mils. (Margin debt vs. credit balances in margin accounts).

Table 2. AR(1)-TGARCH(1,1) Results: effect of joiners/leavers on the returns.

\begin{tabular}{|c|c|c|c|}
\hline & S \& P500 & NASDAQ100 & DJIA \\
\hline \multicolumn{4}{|c|}{ Part a. Mean Equation } \\
\hline$R_{t-1}$ & $-0.031367(0.0407)^{\star}$ & $-0.034611(0.0174)^{\star}$ & $-0.032936(0.0243)^{*}$ \\
\hline$D_{\text {JOIN }}$ & $-0.000213(0.7079)$ & $0.000587(0.7856)$ & $-0.010933(0.0000)^{*}$ \\
\hline$D_{L E A V E}$ & $0.000988(0.0696)^{*}$ & $-0.000296(0.8895)$ & $0.007890(0.0000)^{*}$ \\
\hline \multicolumn{4}{|c|}{ Part b. Variance Equation } \\
\hline$\omega$ & $2.33 \mathrm{e}-06(0.0000)^{*}$ & $2.04 \mathrm{e}-06(0.0000)^{\star}$ & $1.90 \mathrm{e}-06(0.0000)^{*}$ \\
\hline$a$ & $-0.013482(0.0096)^{*}$ & $0.025171(0.0576)^{\star}$ & $-0.000274(0.9794)$ \\
\hline$\gamma$ & $0.180843(0.0000)^{*}$ & $0.104174(0.0000)^{*}$ & $0.162349(0.0000)^{*}$ \\
\hline$\beta$ & $0.903818(0.0000)^{*}$ & $0.915317(0.0000)^{*}$ & $0.902444(0.0000)^{*}$ \\
\hline
\end{tabular}

Notes: Probability of T-statistics in the parentheses. ${ }^{*}$ Significant at $5 \%$ level. 


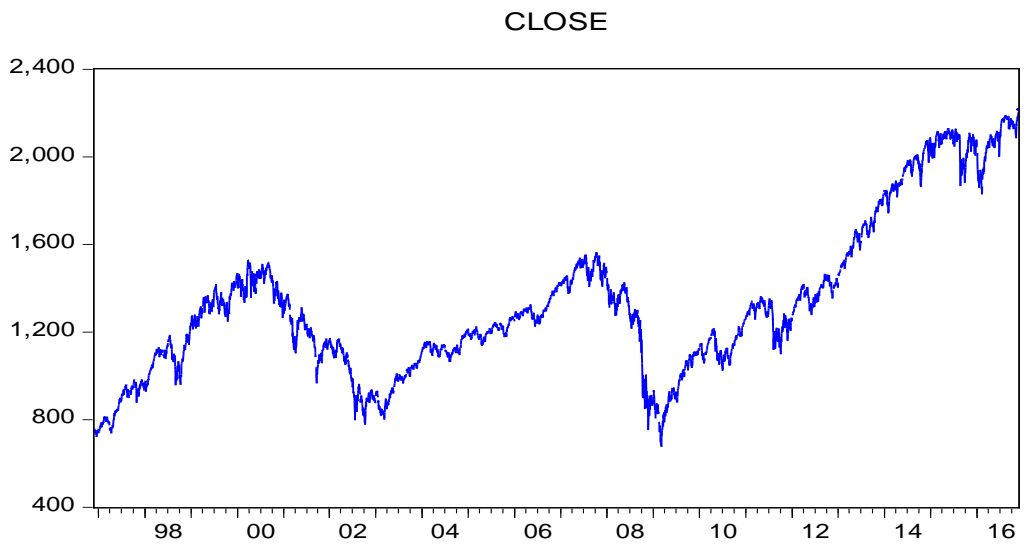

$\mathrm{R}$
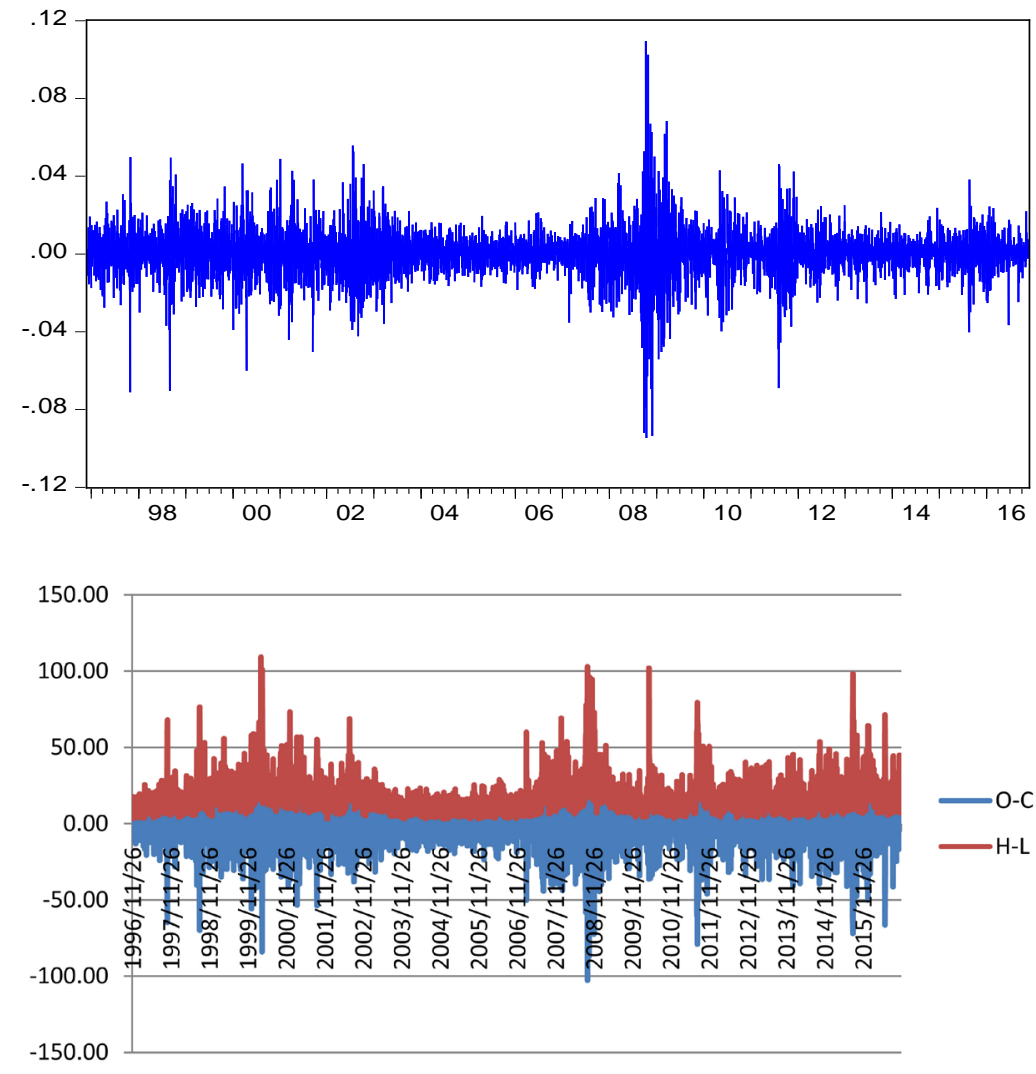

(a)

CLOSE

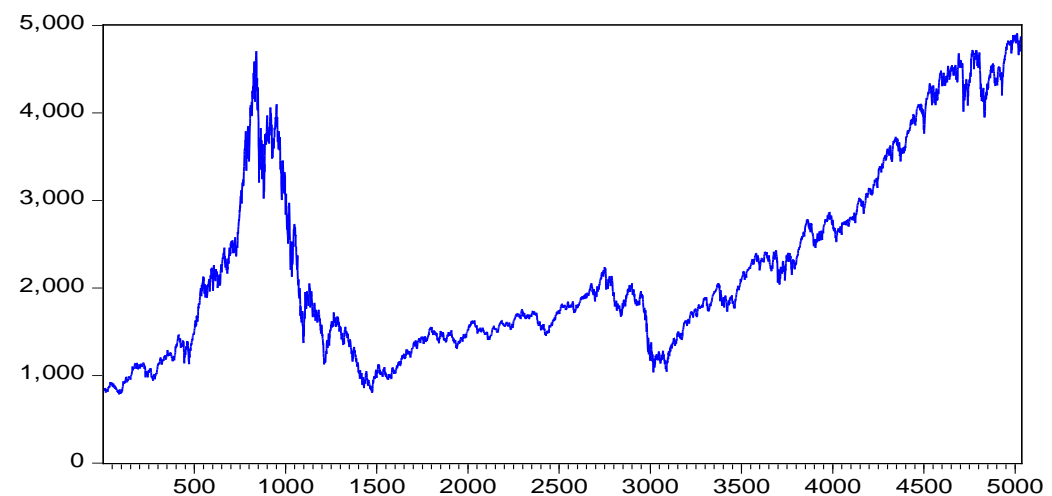


R
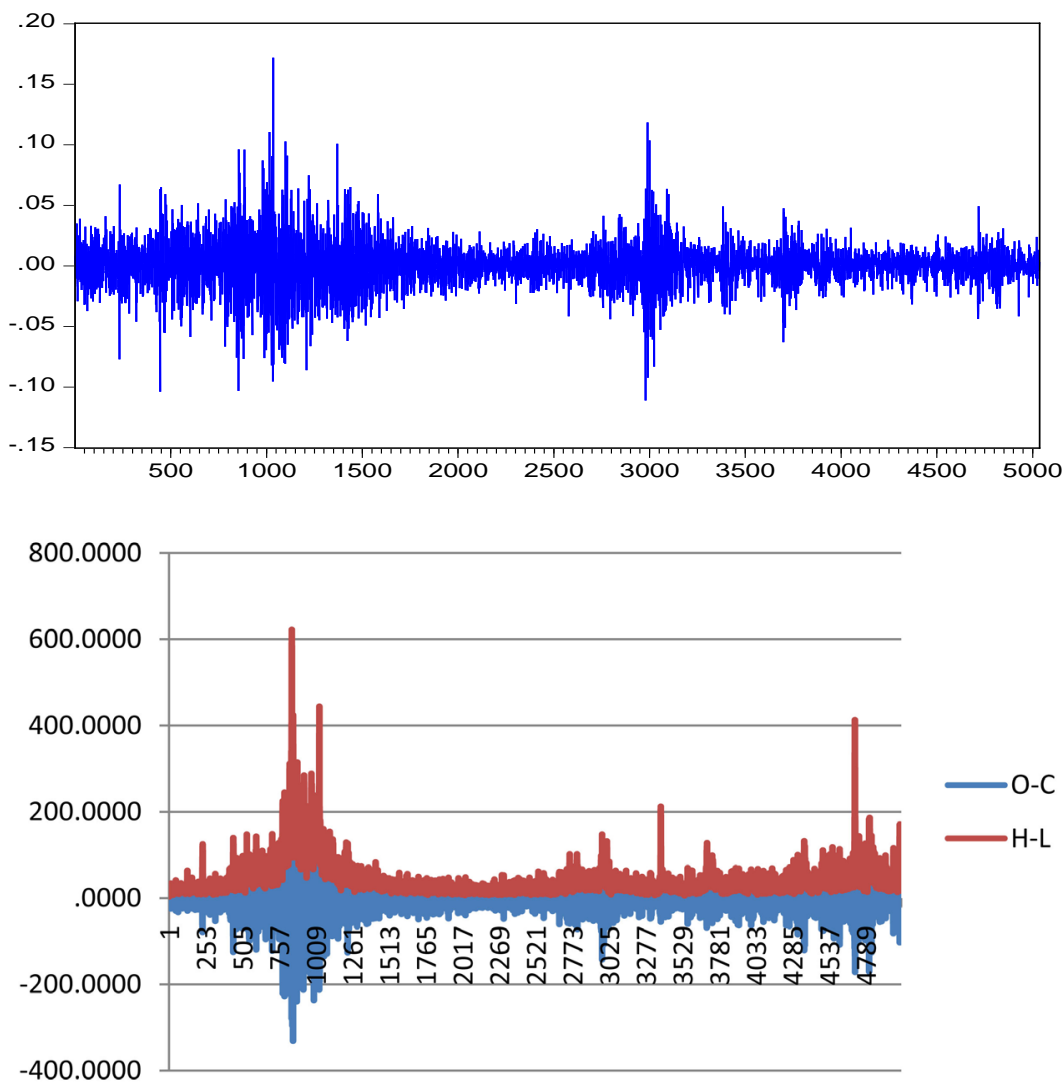

(b)

Close
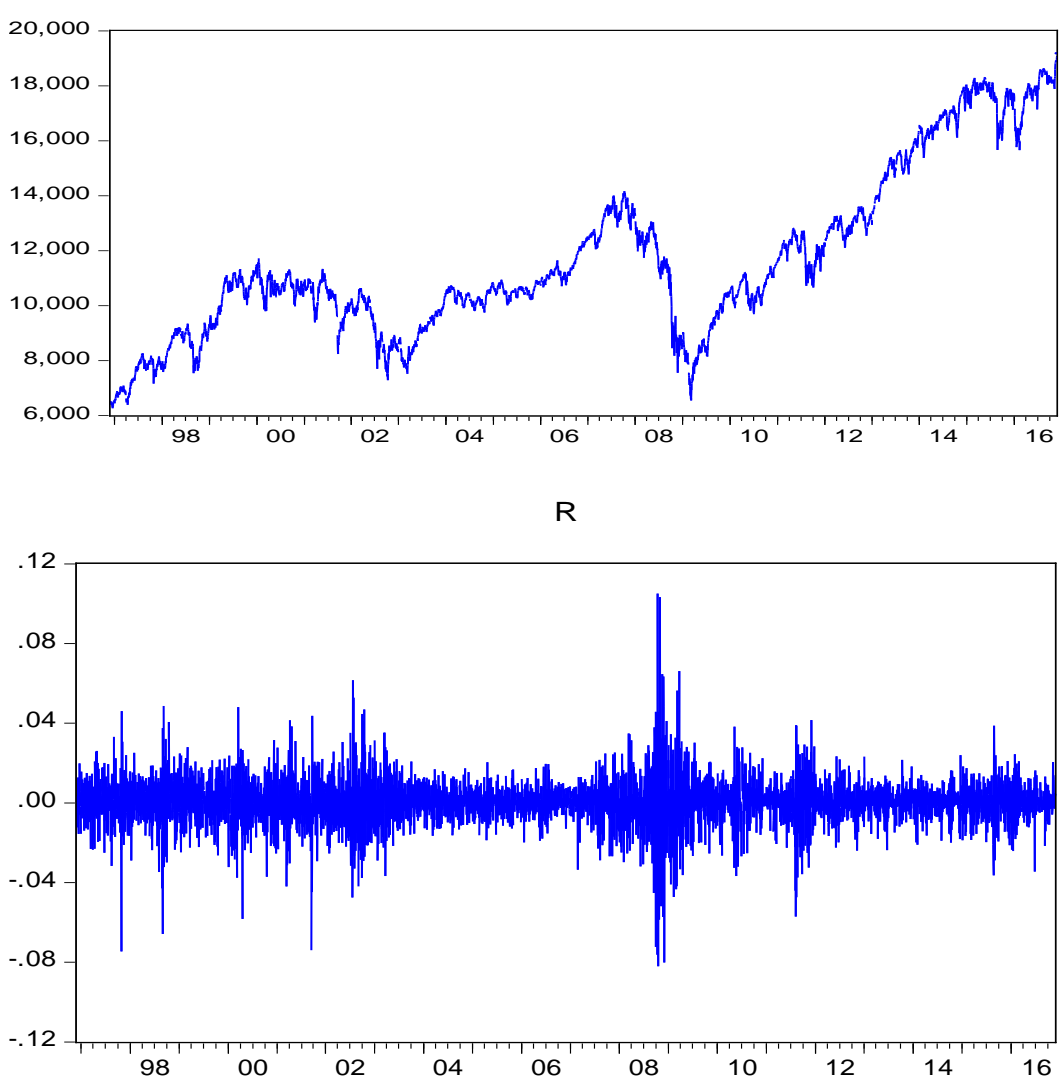


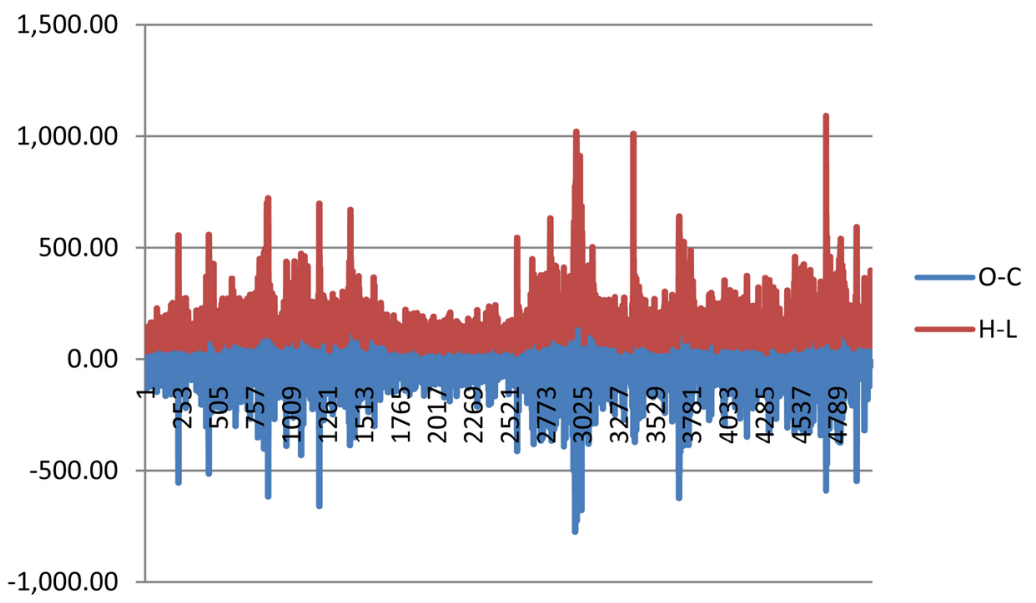

(c)

Figure 2. Plots of Daily Closing Prices, Returns and Open-Close (O-C) vs. High-Low (H-L) prices (1996-2016). (a) S \& P500 index; (b) NASDAQ100 index; (c) Dow Jones Industrial Average Index (DJIA index).

Table 3. AR(1)-TGARCH(1,1) Results: effect of joiners/leavers on the volatility.

\begin{tabular}{cccc}
\hline & S \& P500 & NASDAQ100 & DJIA \\
\hline \multirow{4}{c}{ Part a. Mean Equation } & \\
$R_{t-1}$ & -0.031800 & -0.034772 & -0.052101 \\
& $(0.0378)^{*}$ & $(0.0169)^{*}$ & $(0.0038)^{*}$ \\
\multicolumn{4}{c}{ Part b. Variance Equation } \\
$\omega$ & $1.81 \mathrm{E}-06$ & $1.93 \mathrm{E}-06$ & \\
& $(0.0000)^{*}$ & $(0.0001)^{*}$ & $(.10 \mathrm{E}-05$ \\
$a$ & -0.014801 & 0.025260 & $(0.0000)^{*}$ \\
& $(0.0072)^{*}$ & $(0.0571)^{*}$ & 0.165128 \\
$\gamma$ & 0.182736 & 0.103355 & $(0.0000)^{*}$ \\
& $(0.0000)^{*}$ & $(0.0000)^{*}$ & 0.130717 \\
$\beta$ & 0.902889 & 0.915657 & $(0.0207)^{*}$ \\
& $(0.0000)^{*}$ & $(0.0000)^{*}$ & 0.463634 \\
$D_{\text {JOIN }}$ & $-5.83 \mathrm{E}-06$ & $2.97 \mathrm{E}-06$ & $(0.0000)^{*}$ \\
& $(0.1353)$ & $(0.9059)$ & $-3.91 \mathrm{E}-05$ \\
$D_{L E A V E}$ & $1.39 \mathrm{E}-05$ & $1.21 \mathrm{E}-06$ & $(0.0475)^{*}$ \\
& $(0.0014)^{*}$ & $(0.9618)$ & $-3.81 \mathrm{E}-05$ \\
\end{tabular}

Notes: Probability of T-statistics in the parentheses; ${ }^{*}$ Significant at $5 \%$ level.

from the mean and variance equations of the AR(1)-TGARCH(1,1) asymmetric model under the Normal distributional assumption ${ }^{4}$ for the standardized residuals ${ }^{5}$. Firstly, we find positive effects of leavers announcements to S \& P500 and DJIA stock market returns. Further, we report find negative effects of joiners

\footnotetext{
${ }^{4}$ We report the results from the $\mathrm{AR}(1)-\mathrm{TGARCH}(1,1)$ model with the Normal distributional assumption for the standardized residuals (results from other distributional assumptions, the GED and Student's-t, are qualitatively similar to those reported here). Heteroskedasticity Consistent Covariance (HCC) option is used to compute quasi-maximum likelihood (QML) covariances and standard errors using the methods described by Bollerslev and Wooldridge [25].

${ }^{5}$ Results from asymmetric $\operatorname{AR}(1)-\operatorname{EGARCH}(1,1)$ model (not reported here to save space) are qualitatively similar to those from AR(1)-TGARCH(1,1).
} 
announcements on DJIA stock market returns. There are no significant results reported for NASDAQ100, i.e. investors are neutral to these announcements.

Table 3 reports the effect of joiners and leavers on the variance of returns (volatility) of the stock indices ${ }^{6}$. We find positive effect of leavers announcements on S \& P500 volatility, while a negative effect of joiners announcements on DJIA volatility is reported. Again, no significant results about the effect of joiners and leavers on volatility reported for NASDAQ100.

Finally, all results confirm the empirical finance literature. Asymmetry of news is incorporated into the TGARCH model by the variable $\gamma$; the results show a $\gamma \neq 0$ and significant, and therefore, the impact is asymmetric. Further, positive and significant $\gamma$ parameter for all cases shows that the leverage effect exists and bad news (announcement) increases volatility.

\section{Summary and Conclusion}

Since a huge number of firms are listed/delisted on the stock markets, we consider data information from three major US stock indices to test the link between joiners and leavers announcements and the stock market performance. This paper provides new evidence of this link for the US market. Although we have some evidence about the effect of listing and delisting (joiners and leavers) announcements on stock returns, we know little about these effects on volatility. Therefore, we investigate the effects of these announcements on stock returns as well as volatility using an AR (1)-TGARCH model. Our aim is to extend previous papers by testing two hypotheses: 1) the effect of joiners/leavers results on stock market returns and volatility of three major US indices; and 2) if the asymmetric effect is present in our case. The approach is useful as it gives interesting results which clearly explain the economic importance of delisting/listing results on the US financial market. In particular, we report (a) a positive effect of leavers on stock market returns (S \& P500, DJIA) and (b) a positive effect of leavers on stock market volatility (S \& P500); this is due to the fact that leavers have low liquidity. Leavers announcements help stock market to increase its level of efficiency and performance after delisting. Moreover, we find a negative effect of joiners on DJIA stock market returns and volatility; due to low profitability of these firms (see Figure 1). No effects reported for NASDAQ100 due to the fact that NASDAQ stock market reports high P/E and Price to Book index ratios compared to those from S \& P500 and DJIA. These findings are recommended to financial managers and investors dealing with US stock indices.

This paper uses time series daily data from the US market for a long period; however, annually accounting data is only available for a short period. Further

${ }^{6}$ Floros [26] reports that volatility estimators based on opening, high, low and closing prices are efficient measures. Results from a simple regression of the form $V_{R S, t}=c+a D_{\mathrm{JOIN}}+\beta D_{\mathrm{LEAVE}}$, where $V_{R S, t}=\left[\ln \left(H_{t}\right)-\ln \left(O_{t}\right)\right]\left[\ln \left(H_{t}\right)-\ln \left(C_{t}\right)\right]+\left[\ln \left(L_{t}\right)-\ln \left(O_{t}\right)\right]\left[\ln \left(L_{t}\right)-\ln \left(C_{t}\right)\right]$, are qualitatively similar to those from $\operatorname{AR}(1)-\operatorname{TGARCH}(1,1)$, i.e. we find a similar effect of dummies on volatility VRS $\left(O_{t}, C_{t}, H_{t}, L_{t}\right.$ denote the opening, closing, high and low prices at day $t$, respectively). These results are available from the authors upon request. 
research should examine the spill over effects of joiners/leavers announcements on international financial markets using an event-study methodology.

\section{References}

[1] Doidge, C., Karolyi, A. and Stulz, R. (2017) The U.S. Listing Gap. Journal of Financial Economics, 123, 464-487.

[2] Acharya, V. and Xu, Z. (2017) Financial Dependence and Innovation: The Case of Public versus Private Firms. Journal of Financial Economics, 124, 223-243.

[3] Amihud, Y. and Mendelson, H. (1988) Liquidity and Asset Prices: Financial Management Implications. Financial Management, 17, 5-15.

[4] Pour, E. and Lasfer, M. (2013) Why Do Companies Delist Voluntarily from the Stock Market? Journal of Banking \& Finance, 37, 4850-4860.

[5] Jensen, M. (1989) Eclipse of the Public Corporation. Harvard Business Review, September-October 1989, 64-65.

[6] Sanger, G. and Peterson, J. (1990) An Empirical Analysis of Common Stock Delistings. Journal of Financial and Quantitative Analysis, 25, 261-272.

https://doi.org/10.2307/2330828

[7] Macey, J., O'Hara, M. and Pompilio, D. (2008) Down and Out in the Stock Market: The Law and Economics of the Delisting Process. The Journal if Law and Economics, 51, 683-713.

[8] Park, J., Lee, P. and Park, Y.W. (2014) Information Effect of Involuntary Delisting and Informed Trading. Pacific-Basin Finance Journal, 30, 251-269.

[9] Fama, E. and French, K. (2004) New Lists: Fundamentals and Survival Rates. Journal of Financial Economics, 73, 229-269.

[10] Angel, J.J., Harris, J.H., Panchapagesan, V. and Werner, I.M. (2004) Off But Not Gone: A Study of NASDAQ Delisting. Working Paper, Washington University, Washington.

[11] Errunza, V. and Miller, D. (2000) Market Segmentation and the Cost of Capital in International Equity Markets. Journal of Financial and Quantitative Analysis, 35, 577-600. https://doi.org/10.2307/2676256

[12] Merton, R. (1987) A Simple Model of Capital Market Equilibrium with Incomplete Information. Journal of Finance, 42, 483-510. https://doi.org/10.1111/j.1540-6261.1987.tb04565.x

[13] Lins, K., Strickland, D. and Zenner, M. (2004) Do Non-U.S. Firms Issue Stock on U.S. Equity Markets to Relax Capital Constraints? Journal of Financial and Quantitative Analysis, 40, 109-133. https://doi.org/10.1017/S0022109000001769

[14] Brennan, M. and Subrahmanyam, A. (1996) Market Microstructure and Asset Pricing: On the Compensation for Illiquidity in Stock Returns. Journal of Financial Economics, 41, 441-464.

[15] Pagano, M., Roell, A.A. and Zechner, J. (2002) The Geography of Equity Listing: Why Do European Companies List Abroad? Journal of Finance, 57, 2651-2694. https://doi.org/10.1111/1540-6261.00509

[16] Chaplinsky, S. and Ramchand, L. (2008) From Listing to Delisting: Foreign Firms' Entry and Exit from the U.S. SSRN Electronic Journal, Unpublished Working Paper, University of Virginia, Charlottesville, VA.

[17] Beaver, W., McNichols, M. and Price, R. (2007) Delisting Returns and Their Effect on Accounting-Based Market Anomalies. Journal of Accounting and Economics, $43,341-368$. 
[18] Andersen, T.G., Davis, R.A., Krei $\beta$, J.-P. and Mikosch, T. (2009) Handbook of Financial Time Series. Springer, Berlin.

[19] Reider, R. (2009) Volatility Forecasting I: GARCH Models, Time Series Analysis and Statistical Arbitrage Notes. New York University, New York.

[20] Zakoian, J.M. (1994) Threshold Heteroscedastic Models. Journal of Economic Dynamics and Control, 18, 931-955.

[21] Glosten, L., Jaganathan, R. and Runkle, D. (1993) On the Relation between the Expected Value and the Volatility of the Nominal Excess Return on Stocks. Journal of Finance, 48, 1779-1801. https://doi.org/10.1111/j.1540-6261.1993.tb05128.x

[22] Floros, C. (2011) On the Relationship between Weather and Stock Market Returns. Studies in Economics and Finance, 28, 5-13. https://doi.org/10.1108/10867371111110525

[23] Bollerslev, T., Engle, R.F. and Nelson, D.B. (1994) ARCH Models. In: Engle, R.F. and McFadden, D., Eds., Handbook of Econometrics, Vol. IV, North-Holland, Amsterdam, 2959-3038.

[24] Wang, P. (2003) Financial Econometrics: Methods and Models. Routledge, Abingdon-on-Thames.

[25] Bollerslev, T. and Wooldridge, J.M. (1992) Quasi-Maximum Likelihood Estimation and Inference in Dynamic Models with Time Varying Covariances. Econometric Reviews, 11, 143-172. https://doi.org/10.1080/07474939208800229

[26] Floros, C. (2009) Modelling Volatility Using High, Low, Open and Closing Prices: Evidence from Four S\&P Indices. International Research Journal of Finance and Economics, 28, 198-206.

Submit or recommend next manuscript to SCIRP and we will provide best service for you:

Accepting pre-submission inquiries through Email, Facebook, LinkedIn, Twitter, etc. A wide selection of journals (inclusive of 9 subjects, more than 200 journals)

Providing 24-hour high-quality service

User-friendly online submission system

Fair and swift peer-review system

Efficient typesetting and proofreading procedure

Display of the result of downloads and visits, as well as the number of cited articles

Maximum dissemination of your research work

Submit your manuscript at: http://papersubmission.scirp.org/

Or contact tel@scirp.org 